\title{
Teologi Pengharapan
}

\section{Abstrak}

Ezra Tari, Teologi Pengharapan. Tujuan penulisan adalah untuk memaparkan pandangan teologi pengharapan. Jürgen Moltman dilahirkan di Hamburg pada tahun 1926.Moltmann menempuh ujian masuknya untuk melanjutkan pendidikannya, namun sebaliknya ia pergi berperang sebagai seorang tenaga pembantu di Angkatan Udara Jerman. Mempertemukan antara pandangan postmodern dengan ajaran trinitas ditengah pluralisme dan postmodern. Dengan keragaman pandangan pandangan trinitas apakah masih bisa dipertahankan atau tidak.

Berdasarkan latar belakang masalah di atas, maka penulis meneliti tentang Trinitas dan Agama Plural di tengah Postmodernisme. Jenis penelitian yang digunakan yaitu berdasarkan metode penelitian kualitatif berdasarkan kepustakaan (library research). Penulis mengumpulkan data-data dari pustaka yang berbicara mengenai Trinitas dan Agama Plural di tengah Postmodernisme. Pengumpulan data, juga diperoleh dari observasi atau pengamatan terhadap gejala yang terjadi dalam kehidupan orang percaya. Dari hasil penelitian ditemukan bahwa trinitas masih relevan bagi orang Kristen namun tidak berlaku bagi agama lain. Trinitas merupakan ciri khas ajaran Kristen dan tidak berlaku absolut sesuai pandangan postmodern.

Kata Kunci: Trinitas, Agama Plural, Postmodernisme, Kristen

\section{PENDAHULUAN}

\section{A. Latar Belakang Masalah}

Isu hari terakhir adalah isu yang kembali muncul di abad ke-20 saat ini. Orang selalu bergerak kedepan dan terus mengalami perubahan serta pernyataan yang mengungkapkan bahwa ada hidup setelah kematian. Keadaan ini terjadi karena kehidupan saat ini mengalami krisis yang meliputi lingkungan, kehidupan politis yang tidak berjalan semestinya seperti harapan akan adanya kehidupan yang baik. Harapan surga merupakan impian semua manusia, di mana ada kedamaian, kesejahteraan, dan masih banyak harapan yang manusia inginkan dalam situasi sosial-politik yang tidak menentu.Penulis memilih topik teologi pengharapan sebagai upaya memahami harapan akan hari terakhir, di mana kondisi itu disebut surga. Pengharapan akan pembebasan dari kehidupan 
yang fana dan ketidakberdayaan. Pengharapan akan kehidupan kekal di masa yang akan datang yang penuh sukacita.

\section{B. Pokok Masalah}

Berdasarkan latar belakang di atas, maka penulis merumuskan masalah dengan beberapa pertanyaan sebagai berikut:

1. Bagaimana teologi pengharapan mengubah hidup manusia?

2. Apa yang teologi pengharapan sumbangkan bagi kehidupan beriman?

\section{Tujuan Penulisan}

Tujuan penulisan teologi pengharapan adalah:

1. Memaparkan teologi pengharapan bagi hidup manusia

2. Menguraikan teologi pengharapan bagi kehidupan kita sebagai gereja dalam menyikapi perubahan.

\section{LATAR BELAKANG SEJARAH TEOLOGI PENGHARAPAN}

Teologi harapan atau theologie der Hofnung merupakan karya besar yang diterbitkan tahun 1964.Teologi harapan merupakan karya seorang teolog jerman yang bernama Jürgen Moltman. Molman melihat bahwa iman Kristen dilihat sebagai sesuatu yang berada di masa depan. ${ }^{1}$ Moltmann menempuh ujian masuknya untuk melanjutkan pendidikannya, namun sebaliknya ia pergi berperang sebagai seorang tenaga pembantu di Angkatan Udara Jerman. ${ }^{1}$ Pada 1944, ia sungguh-sungguh terkena wajib militer, dan menjadi tentara di militer Jerman. Ketika diperintahkan ke Reichswald, sebuah hutan Belgia di garis depan, ia menyerah pada 1945 dalam kegelapan kepada tentara Inggris pertama yang ia jumpai. Ia menjadi tawanan 1945-1948 di Belgia dan Inggris sebagai tawanan perang. Pada tahun

\footnotetext{
${ }^{1}$ Harun Hadiwijono, Teologi Reformatoris abad Ke 20, (Jakarta: BPK Gunung Mulia, 2000), 113
} 
1952, belajar teologi dan menjadi pendeta serta menjadi guru besar di Wuppertal pada tahun 1958. Ia mula-mula ditawan di Belgia. Di kamp di Belgia, para tahanan tidak mempunyai banyak kegiatan. ${ }^{2}$

Moltmann dan rekan-rekan setahanan merasa tersiksa oleh kenangan dan pikiran-pikiran yang mengkhawatirkan.Moltmann mengaku telah kehilangan semua pengharapan dan kepercayaan terhadap budaya Jerman karena Auschwitz dan Buchenwald (kamp-kamp konsentrasi tempat orang Yahudi dan yang lain-lainnya yang ditentang Nazi ditahan dan dibunuh). Mereka juga melihat foto-foto yang dipasang secara menantang di gubuk-gubuk mereka, foto-foto yang gamblang tentang Buchenwald dan kamp konsentrasi Bergen-Belsen. Moltmann mengaku bahwa penyesalannya begitu mendalam, sehingga ia sering merasa bahwa ia lebih suka mati bersama-sama dengan rekan-rekannya daripada tetap hidup untuk menghadapi apa yang telah dilakukan oleh bangsanya.

Moltmann bertemu dengan sekelompok orang Kristen di kamp itu, dan seorang pendeta tentara Amerika memberikan kepadanya sebuah Perjanjian Baru dan Mazmur. Perlahan-lahan ia semakin merasakan identifikasi dan mulai mengandalkan iman Kristen. Moltmann belakangan mengaku, saya tidak menemukan Kristus, dialah yang menemukan saya.Setelah Belgia, ia dipindahkan ke sebuah kamp di Skotlandia, dan di sana ia bekerja dengan orang-orang Jerman lainnya untuk membangun kembali daerah-daerah yang rusak karena pengeboman. Keramahtamahan penduduk terhadap para tawanan itu meninggalkan kesan yang mendalam pada dirinya. Pada Juli 1946, ia dipindahkan untuk terakhir kalinya keNorthern Camp, sebuah penjara Britania yang terletak dekat Nottingham, Britania. Kamp itu dioperasikan oleh YMCA (Young Men's Christian Asocatioan) dan di sana Moltmann bertemu banyak mahasiswa teologi. Di Northern Camp, ia menemukan buku Reinhold Niebuhr, Nature and Destiny of Man (Hakikat dan Tujuan Manusia) itu adalah buku

\footnotetext{
${ }^{2}$ Tony Lane, Runtut Pijar: Sejarah Pemikiran Kristiani, (Jakarta: BPK Gunung Mulia, 1990), 238
} 
teologi pertama yang pernah dibacanya, dan Moltmann mengaku bahwa buku itu menimbulkan dampak yang hebat terhadap hidupnya. ${ }^{3}$

Pada tahun 1960-an merupakan periode di mana situasi Eropa dan Amerika terbuka terhadap segala kemungkinan.Perkembangan ekonomi dan materi yang tinggi serta perubahan yang begitu cepat. Pengharapan akan kebebasan dari suasana politik dan penindasan dari bidang ekonomi dan politik menjadi suasana di mana manusia berpikir akan masa depan yang mengagumkan dan tidak pernah dibayangkan sebelumnya. ${ }^{4}$ Teologi pengharapan didasari dari eskatologi Alberth Scheitzer pada abad ke- 20 tetapi dengan penolakan yang begitu radikal.Pencarian tentang masa depan bukan masa lalu atau sekarang sehingga menempatkan iman dalam hubungannya dengan sejarah. Teologi pengharapan menolak dikotomi sejarah kedalam hal yang suci dan sekuler. Pengharapan Kristen merupakan antisipasi sejarah di masa yang akan datang. Teologi pengharapan merupakan teologi kebangkitan melalui kebangkitan Kristus sebagai buah sulung masa depan yang didefenisikan sebagai pencarian kehidupan akan datang. Eskatologi merupakan penyataan penuh kerajaan Allah yang merupakan misi gereja dalam penantian. ${ }^{5}$ Penekanan Pannenberg lebih kepada penyelamatan Allah dalam sejarah yang ditulis tahun 1959. Segala persoalan dititik beratkan pada sejarah yang dibuat Allah dalam kehidupan manusia.Menurut Pannnenberg Allah hanya dapat dijumpai dalam sejarah bukan didalam eksistensi. ${ }^{6}$

Tahun 1965, gerakan Allah mati dan kebangunan ateisme menguat. Ada tiga orang sebagai penganut Teologi Pengharapan, Jurgen Moltman(reformed), Wolfhart Pannenberg (Lutheran), Johannes Metz (Roman Catholic). Jürgen Moltman dilahirkan di Hamburg pada tahun 1926.Moltmann menempuh ujian masuknya untuk melanjutkan pendidikannya. Pada tahun 1952 ia belajar teologi dan kemudian menjadi pendeta Jemaat. Wolfhart Pannenberg (Lutheran)1928, belajar filsafat dan teologi di

\footnotetext{
${ }^{3}$ Wikipedia Bahasa Indonesia, Ensiklopedia bebas, Jurgen Moltmann, download tanggal 8 November 2011, tersedia di id.wikipedia.org/wiki/Jürgen_Moltmann

${ }^{4}$ Richard Bauckhman, Teologi Mesianis, (Jakarta: BPk Gunung Mulia, 1993), 2

${ }^{5}$ David L Smith, Handbook Contemporary Theology, (Grand Rapids: Bridgepoint Books, 2000), 135

${ }^{6}$ Harun Hadiwijono, Op. Cit, 104.
} 
Gottingen, basel, dan heidelberg. Johannes Metz (Roman Catholic) 1928. Teologinya bersifat fundamental yang melihat iman dalam sejarah dan masyarakat.

\section{KONSEP TEOLOGI}

Konsep Moltmann tentang wahyu atau penyataan dikemukakan sebagai sejarah-Firman.Allah menyatakan diri dalam sejarah sebagai rangkuman seluruh sejarah.Sejarah-Firman atau sejarah-janji yang dipandang sebagai wahyu atau penyataan dipandang sebagai sejarah Firman atau sejarah janji Allah yang menampakkan bahwa penyataan Allah itulah yang eskatologis. ${ }^{7}$ Pandangan eskatologi diartikan sebagai janji sebagai dasar harapan di masa yang akan datang. Hal ini menjadi penekanan dalam pemberitaan injil, di mana penekanan yang paling banyak adalah janji akan ciptaan baru pada masa yang akan datang. Pengharapan ini menyangkut keadilan sosial, pemulihan hubungan manusia dan kedamaian untuk seluruh ciptaan.Gereja melakukan perubahan saat ini berdasarkan pengharapan di masa yang akan datang. ${ }^{8}$ Teologi ini menentang struktur dalam masyarakat dan memandang ke arah depan yang membebaskan dari Allah untuk keluar dari penderitaan dan kedamaian dengan seluruh ciptaan.

Moltman menggambarkan Allah sebagai hal yang terdalam dari kehidupan manusia. Allah bukan berada di tempat tinggi namun Ia berjalan mendahului kita menuju masa depan. Allah yang membebaskan kita dari segala kuasa maut, Ia membangkitkan orang mati dan mengajarkan kepada kita masa depan serta orang yang memiliki pengharapan. Gambaran Allah dalam perjanjian lama menurut

\footnotetext{
${ }^{7}$ Ibid . 114

${ }^{8}$ Tony Lane, Op.cit, 239
} 
Moltmann adalah Allah sejarah. Allah menjanjikan kepada Israel pembebasan di masa yang akan datang pada saat penindasan di Mesir dan itu dilaksanakan dalam perjalanan Israel. Allah yang mengambil bagian dalam hidup manusia nyata dalam konsep Allah yang turut menderita. Allah yang disalibkan nyata dalam diri Yesus Kristus, Ia mati dan bangkit dari maut menyatakan akan harapan kebangkitan dari kematian. ${ }^{9}$ Penderitaan Allah bukanlah sesuatu yang dipaksakan dari luar melainkan penyataan bahwa Allah turut menderita dalam penderitaan mahluk ciptaanNya.Penderitaan Allah nyata lewat pengorbanan Yesus di kayu salib, dengan penderitaan itu Allah kita kenal sebagai Allah yang benar-benar merasakan ketidakberdayaan manusia akibat jatuh dalam dosa.Kehadiran Allah dalam dunia tidak berhenti pada saat mengorbankan diriNya di kayu salib. Allah mengutus Roh Kudus sebagai pembawa perubahan dalam gereja, pembaruan itu dilakukan dalam batin manusia.

Gereja merupakan gereja Yesus Kristus dan merupakan gereja yang misioner.Misi mencakup keseluruhan aktivitas manusia keluar dari kegelapan atau perbudakan.Apa yang terjadi dalam penderitaan Yesus adalah penyerahan Anak melalui Bapa, penyerahan AnakNya memperlihatkan suatu penderitaan Allah yang hanya dimengerti dalam kerangka ketritunggal. ${ }^{10}$ Inti teologi harapan Jurgen Moltmann adalah teologi yang mewujudkan praktek dan perealisasian pengutusan Kristus kedalam dunia yang sering disebut sebagai teologia politika. Eskaologi Kristen bukan bersikap pasif dan menerima saja tetapi memiliki harapan yang dapat diubah bagi masa depan. Menurut Moltmann ada tiga dimensi yang harus diperhatikan oleh gereja yakni gereja yang dihadapkan dengan Allah.

Untuk teologi Moltmann adalah perjalanan penemuan ke negara yang tidak diketahui, bahkan tanpa peta apapun, rasa ingin tahu.Hanya dengan Dalam pengertian ini, ziarah ke ide-ide teologis memiliki karakter petualangan bukan perjalanan yang sederhana. Sejak publikasi Teologi of Hope di 1964, Moltmann terus petualangan panjang gagasan teologis

\footnotetext{
${ }^{9}$ Harun Hadiwiyono, Op.cit. 115

${ }^{10}$ Tony Lane, Op.cit. 239
} 
dengan harapan eskatologis, yaitu, harapan bagi Kerajaan Allah, sebagai tema utamanya. Petualangan ide teologis dapat dibagi menjadi dua bagian oleh sebuah titik balik di jalan teologis pada tahun 1978.Kota Meksiko konferensi dengan para teolog pembebasan, teolog feminis hitam dan teolog. Pada akun ini kita dapat memenuhi dua seri yang berbeda dari karya-karyanya: trilogi awal dan kontribusi sistematis untuk teologi. ${ }^{11}$ Argumen Moltmann dalam Allah yang tersalib membangkitkan beberapa pertanyaan: makna penggantian penebusan salib. Namun demikian, argumennya tampaknya menginspirasi teologi dengan vitalitas.Penekanan teologi Moltmann banyak dipengaruhi oleh Wolfhart Pannenberg seorang teolog sistematika.Serta Ernst seorang sejarahwan yang mampu mempengaruhi pemikiran Moltmann dalam mengembangkan teologi harapan. ${ }^{12}$ Kemuliaan ilahi sebagai janji masa depan yakni pembebasan manusia dari keterpurukan dan semua ciptaan.

Teologi Moltmann adalah teologi futuristik di mana Allah adalah bagian dari masa yang akan datang. Bagi Moltmann kekekalan hilang di dalam waktu. Allah memenuhi janjinya tentang masa yang akan datang dalam janji sebuah harapan yang akan diwujudkan. Harapan akan masa depan atau eskatologi dimengerti sebagai keterbukaan akan masa depan. Masa akan datang adalah suatu kuantitas yang tidak dikenal baik manusia maupun Allah. Kematian dan kebangkitan Kristus adalah jaminan Allah akan masa yang akan datang yakni kebangkitan akhir. Manusia seharusnya tidak pasif dalam menanti masa depan dan melakukan perubahan masa kini sebagai wujud pengharapan masa datang. Tujuan gereja adalah membawa perdamaian sosial, melakukan revolusi yang pantas, dan melakukan pengharapan masa depan pada saat ini. ${ }^{13}$

Moltmann mengungkapkan teologinya bahwa kristologi menjadi eskatologi. Pembangkitan Kristus yang disalibkan berarti bahwa ia mempunyai suatu masa depan ke arah mana iman kepada Kristus yang bangkit, semua pernyataan dan keputusan tentang Dia yang mengandaikan masa depan.

\footnotetext{
${ }^{11}$ Grenz, Stanley J. dan Roger E. Olson, ed. Twentieth Century Theology, (Downers Grove: InterVarsity Press.1992), 173

${ }^{12}$ Harvie M Conn, Op. Cit, 77

${ }^{13}$ Ibid, 79-80.
} 
Iman paskah mengajarkan kepada kita untuk mengerti bahwa Yesus ada hubungan dengan masa depan. ${ }^{14}$ Kategori-kategori adalah pengertian tentang penyataan ilahi sebagai janji dan suatu pengertian tentag sebagai misi.Teologi menurut Moltmann bahwa mengatasi keterbatasannya kepada gereja, iman dan terarah kepada kebenaran dari semuanya dan keselamatan dari dunia yang terpecah.Hermeneutik yang dikembangkan adalah memerhatikan peristiwa masalalu sebagai janji di masa datang.

Teologi pengharapan mengangkat pertanyaan tentang bentuk konkret yang diambil oleh suatu pengharapan eskatologis yang hidup dalam masyarakat modern.Moltmann membuat konsep tentang janji masa depan dengan prinsip: janji mengemukakan kedatangan suatu kenyataan yang belum ada. Janji memprakarsai suatu sejarah yang mengarah kepenuhannya dengan membangkitkan pengharapan manusia akan pemenuhan janji. Janji menciptakan kesadaran masa lalu dan masa depan yang membagi kenyataan kedalam situasi. Perluasan sejarah janji meninggalkan suatu kelebihan menunjukkan pemenuhan yang lebih lanjut. Janji eskatologis adalah untuk suatu masa depan yang final yang secara keseluruhan sesuai dengan kehendak Allah. Janji itu belum memperoleh jawabannya karena menarik pikiran kita tentang masa depan dan pengharapan yang kreatif.

Pusat kristologi dan dasar teologi pengharapan Moltmann adalah pemahamannya tentang kebangkitan Yesus yang disalib sebagai suatu peristiwa janji eskatologis. Argumen Moltmann mengenai kenyataan yang dihadapi dan terbuka pada transformasi dari janji ilahi.Dealektika salib dan kebangkitan berarti bahwa Yesus yang disalibkan dan kebangkitan identitasNya dalam kontradiksi yang total.Pengalaman yang dialami Yesus sebagai Allah yang tersalib merupakan pembaruan. ${ }^{15}$ Menurut Moltmann menggambarkan janji Allah melalui Yesus Kristus yang dikerjakan bagi gereja.Kristus hadir dalam parousia yaitu kehadiranNya yang kedua kali untuk menghakimi manusia. Gereja membarui hidup ini menurut Moltmann harus melalui proses yang dialami manusia.

\footnotetext{
${ }^{14}$ Richard Bauckhman, Op.Cit, 27

${ }^{15}$ Ibid, 42
} 
Pada saat ini gereja dihadapkan dengan dua krisis yakni krisis relevansi dan identitas. Menurut Moltmann kejadian salib memperkenalkan kita akan tabiat Allah. Pengaruh Pannenberg terhadap Moltmann cukup besar yang berbicara tentang penyataan Allah dalam Kristus seperti yang disaksikan oleh Alkitab. ${ }^{16}$

Apa yang terjadi pada Yesus yang tersalib di mana Ia diserahkan oleh Allah sebagai diriNya sendiri. Penyerahan Allah menandakan keadaan sosial yang menyangkut ketritunggalan.Doktirn ketritunggalan merupakan kebebasan manusia dari belenggu kemiskinan.Pemahaman doktrin ketritunggalan bukan merupakan teologia yang abstrak melainkan suatu yang digunakan dasar pembebasan misi pembebasan gereja dalam masyarakat modern saat ini. ${ }^{17}$ Pembebasan itu dimulai saat ini menuju masa depan. Eskatologi berbicara tentang Kristus yang akan nyata pada masa depan. Yesus memberikan kepada eskatologi menyangkut pribadi dan sejarah Yesus yang memberikan ujian kepada jiwa eskatologi.

Moltmann menitikberatkan teologi harapan isi alkitab dengan konsep harapan eklesiologi.Moltman menemukan dalam alkitab tentang harapan masa depan dengan harapan yang dijanjikan. Teologi harapan dapat dibagi dua yakni harapan dan janji. Harapan dan janji merupakan pergerakan mennati masa depan dengan bertumpu pada kebangkitan Kristus. ${ }^{18}$ Pengharapan kristiani bukan hanya berbicara tentang masa depan namun memosisikannya sebagai kekuatan sebisa mungkin dalam menata masa depan. Teologi kekristenan berbicara tentang Yesus Kristus dan masa depan itu sendiri.Jika iman didasarkan pada harapan yang diasumsikan sebagai dosa ketidakpercayaan didasarkan pada keputusasaan.

Eskatologi merupakan janji yang dideklarasikan dalam realitas sejarah seperti janji pembebasan yang dilakukan Tuhan dalam perjanjian lama.Kunci masa depan oleh Moltmann digambarkan dalam

\footnotetext{
${ }^{16}$ Harun Hadiwiyono, 105.

${ }^{17}$ Tony Lane, 240

${ }^{18}$ David L Smith, Op. Cit, 136
} 
parousia. Parousia digambarkan sebagai janji kedatangan Yesus Kristus.Janji tentang kebangkitan sudah dinyatakan secara penuh sebagai kebenaran. Misi mesianis dan misi kreatif Roh Kudus dalam menuntun manusia kearah masa depan.Teologi pengharapan yang diperkenalkan oleh Pannenberg lebih kepada realitas Allah dan pengakuan dari realitas dalam filsafat dan dogmatika.Pengalaman sejarah, tradisi, dan kritik eksegesis bersama dengan filsafat dan refleksi teologi dalam implikasi pengalaman yang didiskusikan tentang realitas Allah.

Allah hadir dalam sejarah yang berjanji tentang masa depan dalam sejarah yang tertulis dalam alkitab. Peletakan Allah yang berkarya dalam sejarah merupakan solusi bagi teologi fundamental.Pendekatan kita dengan relasi setiap orang dengan Yesus sejarah dilakukan dengan pendekatan sejarah perjanjian lama.Moltmann dan Pannenberg melihat iman Kristen merupakan sebuah eskatologi yang merupakan masa depan. Kerajaan Allah dimengerti sebagai eskatologi yang dibawa oleh Allah sendiri. Yesus yang datang kedalam dunia dimengerti sebagai realitas kerajaan Allah yang datang kedalam dunia.Dia ada di masa lalu dan suat waktu akan datang di masa yang akan datang.

\section{ANALISIS}

\section{A. TINJAUAN ALKITABIAH}

Penderitaan adalah merupakan eskatologi yang signifikan dalam masalah transendensi dan imanensi.Sejarah dunia diangkat dalam sejarah dalam keilahian Allah yang bergantung dalam sejarah dunia.Tuhan yang benar-benar hadir dalam sejarah dunia. Moltmann mengungkapkan bahwa pengharapan Kristen bukan hal yang abstrak tetapi penderitaan membawa pada masa depan yang terjadi pada Kristus yang diperkenalkan dalam pemurnian yang merupakan tanda bahwa sejarah telah berakhir tetapi kehidupan nyata manusia masih ada dan sejarah itu sendiri. ${ }^{19}$

Moltmann mengingatkan kita tentang kedatangan Tuhan seperti pencuri (II Petrus 3:10-11). Moltmann melihat masa depan sebagai teologia kalam dengan menunjukkan teologi dialektika.

\footnotetext{
${ }^{19}$ Grenz, Stanley J. dan Roger E. Olson, Op.Cit, 175
} 
Teologia pengharapan mengungkapkan tentang eskatologi atau kebangkitan atau penyempurnaan di masa depan. Pada masa lampau Alkitab terus memberitakan pengharapan masa depan yang sedang dimulai, hal itu dikisahkan dalam Kisah rasul 2:17, Ibrani 1:2, 1 Yohanes 2:18. Kerajaan Allah dihantar oleh politk dan revolusi yang telah diproklamirkan oleh Yesus Kristus (Kis 28:3031).Masa akan datang bukan hanya kuantitas yang tidak diketahui bagi manusia. Menurut Moltmann Allah ada pada masa datang didorong oleh waktu. ${ }^{20}$

Eskatologi berpusat pada manusia, di mana manusia memandang pada masa depan bukan manifestasi melainkan kebangunan utopia di dunia. Moltmann menegaskan bahwa Allah tidak meletakkan dasar otoritarian yang digunakan dalam merealisasikan masa datang.Kerajaan Allah dapat dimasuki melalui iman beriman kepadaNya dan kerajaan itu bukan revolusi (Rm 14:17). Masa depan bukan saja kuantitas yang tidak diketahui bagi manusia tetapi merupakan kuantitas yang diketahui Allah. Kristus sebagai duta Allah telah melaksanakan tugas pengungkapan Allah dalam kematian dan kebangkitan di kayu salib. Kebangkitan orang mati merupakan harapan masa depan seperti yang diberitakan murid Yesus. Kedatangan Tuhan Yesus yang dikenal dengan Parousia Kristus merupakan penyataan yang terjadi pada Kristus yang diungkapkan dan masih dinantikan. Harapan kristiani tentang masa depan, di mana Kristus akan datang belum diwujudkan seperti janji Allah (Bnd. 2 Kor 1:20).

Kristus telah dimuliakan dan berjanji akan hadir dalam apostolat gerejaNya. Apostolat menyangkut pemasyuran injil dengan firman dan sakramen serta orang yang memasyurkanNya dalam persekutuan.Ia mengidentikkan diriNya dengan kata-kata: barangsiapa mendengarkan kamu, ia mendengarkan Aku (Luk 10:16). Pemasyuran akan jani Allah seperti yang dilakukan Paulus yang senantiasa memberitakan injil di mulut dan tubuhnya (2 Kor 4:10). Allah menurut teologi Motlmann memberi contoh Allah yang ada di masa lalu dan sekarang.Pannenberg berbicara tentang sejarah sebagai alat janji yang dinampakkan Allah dalam hidup manusia. Yesus sebagai janji

\footnotetext{
${ }^{20}$ Richard Bauckhman, Op.Cit, 81-82
} 
kedatangan di masa yang akan datang. Perjanjiannya kepada Israel dan Kristus yang ada di dalam dunia adalah partisipasiNya dalam sejarah.

Sejarah dalam pengalaman nyata setiap orang dalam gambar Allah yang akan dinyatakan pada kedatanganNya kedua kali. Metz lebih konsen melihat gambaran kedatanganNya.Mertz melihat fakta kristus yang ada sebagai fakta sejarah tetapi bukan dari kualitas sejarah itu sendiri.Sejarah yang nyata dalam kedatangan yang kedua kali yang juga dilihat dalam kepenuhan Allah di dunia dalam diri Kristus.

Wolfhart Pannenberg melihat pernyataan dalam Kisah para rasul 4:12, tidak ada nama lain selain Yesus yang olehNya kita diselamatkan.Pannenberg sesungguhnya tidak konsisten dengan eksistensi Yesus di masa lalu tetapi masa depanNya. Yesus Keluar dari masa depan kepada masa sekarang dan lalu. Kristologi Metz lebih tradisional, di mana inkarnasi merupakan kisah objektif sejarah di mana Tuhan menjadi hal terpenting dalam sejarah.

Pannenberg mengungkapkan bahwa kebangkitan Kristus kunci dari pemahaman sejarah.Tidak seperti Moltman, Pannenberg melihat bahwa pergumulan iman Kristen dengan peristiwa sejarah kebangkitan Kristus.Teologi pengharapan mengadopsi pandangan bahwa dosa lebih dari kekristenan tradisional dan menyerang teologi liberal tentang harapan masa depan. Moltmann melihat keristenan dengan mengidentifikasi bahwa masyarakat menggunakan masa depan sebagai motivasi dalam penantian yang ada ditangan Allah.Untuk Metz, keselamatan merupakan bagian proses sejarah yang terjadi sekarang.

Gereja merupakan agen perubahan dalam dunia, iman Kristen merupakan praksis dalam sejarah masyarakat yang dimengerti sebagai harapan dan solidaritas Allah dalam Yesus sebagai Allah tinggal dan mati bagi manusia.Keselamatan menurut Metz lebih dari apa yang dilakukan dan sesuatu tentang Yesus lebih dari iman kepadaNya.Kristus hadir pada orang-orang yang miskin dan hina (Mat 25:31-46). Gereja menantikan kerajaan sebagai masa depan segala mahkluk. Gereja harus mengartikan misinya dalam dunia untuk melakukan pembaruan dan mengalami proses dalam 
bidang ekonomi, politik dan kebudayaan. Gereja merupakan umat yang sedang bepergian (Ibr 13:13,14). Gereja memasukkan masyarakat kedalam perspektif eskatologis.Masyarakat yang menciptakan kedamaian, kebenaran dan kemasyarakatan yang terus-menerus keluar menuju masa depan. Teologi harapan ini cenderung menuju revolusi hidup yang membawa kita terus menerus dibarui.

Kenyataan masa kini tidak mempunyai kemungkinan yang imanen untuk mentransedensikan kecenderungan yang mengarah pada ketiadaan. Allah menciptakan masa depan yang baru secara kualitatif, namun dalam kesetianNya pada ciptaan yang lama, Ia membawanya ke dalam yang baru. Moltmann mengatakan bahwa pengharapan akan kebangkitanlah yang memungkinkan untuk mengasihi kenyataan yang berada di bawah kuasa kematian. Terang itu telah datang kedalam dunia tetapi manusia lebih menyukai kegelapan sebab perbuatan-perbuatan mereka jahat (Yoh 3:19).Tidak ada seorangpun yang mengaku Yesus itu Tuhan selain oleh Roh Kudus (1 Kor 12:3).

Kemuliaan tidak diletakkan di atas kepada kepala orang-orang yang berkuasa.Bagi orangorang percaya, Kristus disalib dibuat menjadi kebenaran Allah dan bagi mereka kekuasaan politis kehilangan keabsahan agamawinya.Barangsiapa yang berseru kepada Allah dalam penderitaan mengumandangkan teriakan kematian dari Kristus, Anak Allah yang sedang menderita.Allah yang disalibkan adalah tentang kasih kasih yang mengosongkan dirinya dalam solidaritas dengan yang lain. Salib adalah peristiwa dari kasihNya yang mau menderita dan benar-benar hidup.Eskatologis dari teologi pengharapan adalah melayani untuk membuka gereja terhadap sejarah, dunia dan masa depan dalam terang Kristus.

\section{B. DAMPAKNYA BAGI JEMAAT}

Munculnya ajaran ajaran yang tidak sesuai dengan prinsip dasar Alkitab (kebenarankebenaran Alkitab) mesti disikapi dengan serius agar warga jemaat tidak terombang-ambing 
dengan berbagai pengajaran yang membingungkan, bahkan ada yang mempersoalkan jantung kebenaran Alkitab yakni pendamaian lewat Salib yang bermuara pada kebangkitan. Misi Yesus sangat efektif karena dicirikan oleh perkataan (pemberitaan) dan sekaligus perbuatan (kesaksian), dan yang satu menjelaskan yang lain. Masalah terbesar Gereja dewasa ini adalah bahwa kesaksiannya (cara hidupnya, gaya hidupnya) tidak selaras dengan ajarannya; tidak selalu melakukan apa yang diajarkannya. Kesaksian dan pewartaan tidak saling berhubungan. Kita menghadapi krisis keteladanan: keteladanan pelayan terhadap warga jemaat dan masyarakat, yang pada gilirannya pula krisis keteladanan gereja dan jemaat terhadap sekitarnyaakibatnya, misi kita tidak efektif.

Gereja-gereja di Indonesia harus senantiasa hidup dalam realisme yang berpengharapan”, begitu pesan almarhum T.B. Simatupang.Dengan realisme, kita sebagai gereja Tuhan diajak oleh Tuhan "bertolak ke tempat yang dalam" (Lukas 5:4) untuk mendalami realitas kehidupan kita dan menemukan diri kita, kekuatan dan kelemahan, dengan segala cidera dan berkat yang ada pada kita.Tetapi kita tidak berhenti di situ.Kita hidup dalam pengharapan. Kita adalah bagian dari kawan sekerja Allah membangun masa depan yang lebih baik. Karena itu kita terus bertanya kepada Tuhan, Kalau begitu, apakah yang harus kami perbuat(Kis. 2:37).

Menegaskan identitas kita sebagai gereja, baik identitas teologis maupun etis, untuk kemudian menjalani komitmen hidup seperti itu.Itu berarti sebuah panggilan untuk hadir sesuai dengan identitas eklesiologis yang diberikan kepada kita oleh Tuhan sendiri. Allah diutus ke dalam dunia untuk dunia, berada di dalam dunia, tetapi bukan dari dunia.Setiap kegiatan gereja merupakan tanda kehidupan baru itu, baik bila jemaat berkumpul, maupun bila menyebar untuk melayani dan bersaksi di tengah-tengah dunia.Jemaat adalah arak-arakan yang dinamis dan terbuka serta mengundang semua orang melalui kesaksian hidup, pelayanan dan pemberitaannya untuk ikut dalam arak-arakan ini menuju kepenuhan hidup di dalam Kerajaan Allah.Di dalamnya ada 
pengakuan iman bahwa arak-arakan ini senantiasa dibina dan dipelihara oleh Roh Kudus dan Firman Allah di dalam seluruh kehidupan dan segala kegiatannya di tengah-tengah dunia.

Melalui pembenahan kualitas penatalayanan yang ada, sarana-sarana kesaksian tersebut yang selama ini menjadi alat kesaksian berkembang menjadi wujud kesaksian itu sendiri, sehingga sarana-sarana tersebut mewujudkan tanda-tanda Kerajaan Allah di bumi dalam kehidupan sosial, politik, dan ekonomi. Mandat alkitabiah agar gereja jangan menjadi serupa dengan dunia (Roma 12:2) menjadi tanda awas bagi kita untuk terus menilai diri, sudah seberapa berarti (significant) kehadiran kita di tengah masyarakat.Agar mendapat tempatnya yang benar, yaitu sebagai elemen kemajemukan yang menghidupkan dan memperkaya kesatuan.Suatu pengakuan bahwa ketertutupan dan perpecahan adalah pengingkaran terhadap Yesus Kristus sebagai satu-satunya dasar keesaan gereja.

Dalam relasi itu, terdapat suatu dinamisme yang merangkum banyak hal yang ikut berperan dalam relasi yakni: karya Allah dan usaha manusia, sarana komunikasi, sikap dan aktifitas secara sadar maupun tidak sadar. Di situ, keutamaan hidup teologal yakni iman, pengharapan dan kasih dipahami sebagai komunikasi pribadi manusia dengan Tuhan.Dengan anugerah iman, manusia dimampukan untuk mengenal rencana Allah, percaya pada sabda Allah, dan menyerahkan hidupnya pada Allah sebagai andalan hidupnya.Melalui anugerah harapan, manusia merindukan Allah sebagai tujuan hidupnya.Harapan menjadi sarana yang memampukan manusia mengatasi segala hambatan, cobaan, dan kesulitan yang dijumpainya dalam perjalanan menuju Allah. Dengan anugerah kasih, manusia menerima Allah sebagai kasih (1Yoh 4:8,16). Tanggapan atas Allah yang adalah kasih itu memampukan manusia mengambil bagian dalam hidup Allah sendiri dan pelayanan kepada sesama.

Pengharapan dijelaskan dalam kisah para rasul 24:15, Aku menaruh pengharapan kepada Allah, sama seperti mereka juga, bahwa akan ada kebangkitan semua orang mati, baik orang-orang yang 
benar maupun orang-orang yang tidak benar.Oleh Dia kita juga beroleh jalan masuk oleh iman kepada kasih karunia ini ( $\mathrm{Rm}$ 5:2). Di dalam kasih karunia ini kita berdiri dan kita bermegah dalam pengharapan akan menerima kemuliaan Allah.Pengharapan akan kepenuhan juga menjadi harapan seluruh umat bahwa pengharapan kami akan kamu adalah teguh, karena kami tahu, bahwa sama seperti kamu turut mengambil bagian dalam kesengsaraan kami, kamu juga turut mengambil bagian dalam penghiburan kami (II Kor 1:7).

Efesus 1:18menjelaskan bahwa supaya Ia menjadikan mata hatimu terang, agar kamu mengerti pengharapan apakah yang terkandung dalam panggilan-Nya: betapa kayanya kemuliaan bagian yang ditentukan-Nya bagi orang-orang kudus. oleh karena pengharapan, yang disediakan bagi kamu di sorga (Kol 1:5). Tentang pengharapan itu telah lebih dahulu kamu dengar dalam firman kebenaran, yaitu Injil.Sebab siapakah pengharapan kami atau sukacita kami atau mahkota kemegahan kami di hadapan Yesus, Tuhan kita, pada waktu kedatangan-Nya, kalau bukan kamu? (I Tes 2:19). Titus 3:7menjelaskan supaya kita, sebagai orang yang dibenarkan oleh kasih karunia-Nya, berhak menerima hidup yang kekal, sesuai dengan pengharapan kita.Tetapi kami ingin, supaya kamu masing-masing menunjukkan kesungguhan yang sama untuk menjadikan pengharapanmu suatu milik yang pasti, sampai pada akhirnya (Ibr 6:11).

Pujian kepada Allah dan Bapa Tuhan kita Yesus Kristus, yang karena rahmat-Nya yang besar telah melahirkan kita kembali oleh kebangkitan Yesus Kristus dari antara orang mati, kepada suatu hidup yang penuh pengharapan (I Ptr 1:3). Setiap orang yang menaruh pengharapan itu kepada-Nya, menyucikan diri sama seperti Dia yang adalah suci (I Yoh 3:3). Topanglah aku sesuai dengan janji-Mu, supaya aku hidup, dan janganlah membuat aku malu dalam pengharapanku (Maz 119:116).

\section{KESIMPULAN}

Teologi Moltmann membuka struktur-struktur hermeneutik untuk menghubungkan alkitab dengan dunia modern.Teologi pengharapan adalah benar-benar keliru untuk gerakan untuk sistem yangmenghasilkan tidak ada harapan sama sekali. Pada besar dapat disebut angan-angan untuk 
sementara iman Kristen ortodoks dibangun pada kepastian sejarahkehidupan, kematian, dan kebangkitan Yesus Kristus. Teologi harapan tidak adayakin atau yang kuat untuk membangun. Masa depan harus dibangun pada fakta-fakta historis yang kuat di masa lalu bukan berharap untuk apa yang mungkin.Pusat teologi Moltmann adalah perhatian konkrit terhadap hal kristologis dan eskatologis.

Teologi hanya terbuka kalau dia terbuka dihadapan Allah dan sudah dibuka oleh Allah kepada dunia.Situasi yang benar menurut Moltmann adalah jika teologi mau didialogkan dengan Allah.Moltmann membandingkan pergumulan Yakub di sungai Yabok.Teologi kita seharusnya dibangun dalam terus-menerus mencari konsep, citra dan symbol dari kita.Doa yang ditulis Motlmann adalah dengan ekspresi trinitas, eskatologis, yang berorientasi baik dalam praksis maupun pada doxologi kepada perkembangan yang akan terjadi. Teologi Moltmann membuka relevansi bagi dunia modern yang diperoleh tidak hanya tanpa menyerahkan keistimewaan-keistimewaan yang sentral dari iman alkitabiah.Iman historis Kristen diperoleh secara positif dengan dealktis dan eskatologis. Teologi Moltmann terbuka terhadap dunia dan tidak berada dalam ketegangan dengan pusat Kristologis.Moltmann tidak melakukan akomodasi terhadap nilai-nilai konservatif, liberal, ataupun radikal tetapi mempunyai sisi yang kritis dan solidaritas yang konstan dengan anggota masyarakat yang tersisih. Penambahan akan eklesiologi trinitas akhir-akhir ini sudah merupakan penyelesaian eskatologis oleh struktur teologis dalam gereja.

\section{A. SIKAP}

Gereja harus selalu memiliki hubungkan dengan orang lain sebagai hamba Kristus untuk menyatakanpengharapan masa depan.Teologi sukacita danGereja dalamkuasa Roh. Dealektika penderitaan dan sukacita sertaAllah yang disalibkan.Teologi pengharapan merupakan interpretasi atas salib Yesus.Mengingatkan kita penyataan Allah dalam sejarah,kepenuhan akan janjiNya dankepastian sejarah dan janji. 
Seorang Kristen mempunyai cara hidup, gaya hidup, sikap hidup (etika Kristen) berdasarkan pandangan hidup Kristen. Kasih, yang menjadi prinsip etika Kristen di dasarkan pada sebuah pandangan hidup (kebenaran), sumber pemaknaan dari tindakan kasih itu. Dengan demikian, spiritualitas menunjuk pada kesatuan gaya hidup dengan pandangan hidup yang mendasarinya yang keluar dari hati. Gaya hidup yang bermakna karena gaya hidup itu berdasarkan atau berakarkan pada sebuah sumber pemaknaan hidup yaitu Allah sendiri di dalam Yesus Kristus. Max L. Stackhouse, seorang etikus kenamaan mengatakan bahwa agar sebuah tindakan (gaya hidup) itu bermakna maka etika itu mesti sekaligus menyangkut hal-hal yang penting di dalam soal-soal praktis dan secara jelas berakar pada pemahaman tertentu mengenai "kenyataan yang ada di balik semua kenyataan" (yang kita sebut Allah). Karena itu, "makna”, bagi Stackhouse adalah "apa yang dipercayai sebagai sesuatu yang bersifat harus (mengasihi) dan yang sekaligus dipandang mulia untuk diperhatikan, untuk menuntut kesetiaan dan ketaatan kita (kebenaran) yang muncul dari dalam hati”.

Gaya hidup mengasihi itu adalah substansi iman Kristen.Gaya hidup mengasihi itu sungguh mulia adanya karena ia berasal dari Allah di dalam Yesus Kristus (kebenaran), tidak hanya dibenarkan dengan pikiran (akal) tetapi juga dengan hati dan dengan segenap jiwa (Mat 22:37-39). Bahwa kemuliaan atau kebenaran bagi seorang Kristen adalah dalam gaya hidupnya yang mengasihi. Karena ia keluar dari dalam hati, jiwa dan akal, maka gaya hidup yang seperti itu dinikmati, bukan beban.

\section{B. RESPON}

Apokaliptik menjelaskan sifat masa depan temporal injil paulus dan menunjukkan suatu kejadian pada akhir zaman yang bersifat universal kosmis dan menentukan. sedangkan eskatologi menjadi istilah untuk yang akhir. Dibandingkan dengan apokaliptik yahudi pada waktu itu pengharapan Paulus terhadap intervensi Allah yang segera datang kedalam sejarah umat manusia itu diperkuat.Jadi keristenan kita didalam dunia ini mencakup ketegangan yang 
tidak terelakkan yang berubah-ubah antara sukacita dan siksaan.paulus hanya tahu bahwa zaman antara kebangkitan kristus dan parusia adalah waktu yang diberikan kepadanya sebagai rasul bagi bangsa-bangsa bukan yahudi.

Dimensi-dimensi kosmik dari misi Kristen ini dikembangkan khususnya didalam suratnya kepada jemaat di roma, keselamatan untuk semua mungkin kunci dari seluruh surat tersebut. Misi berarti pemberitaan tentang kedudukan Kristus sebagai Tuhan atas segala realitas dan undangan untuk tunduk kepadanya.makna pelayanan paulus adalah memberitakan kristus sebagai Tuhan. Dalam pemikiran paulus gereja dan dunia dipersatukan dalam suatu ikatan solidaritas.Didalam Kristus Allah mendamaikan dirinya sendiri dengan zaman.Sehubungan dengan soal eskatologis, gereja oleh Paulus adalah eskatologis sementara.Kebenaran Allah harus ditafsirkan sebagaipemberian kepada paguyuban komonitas bukan individu.Orang Kristen adalah paguyuban yang kudus; orang kudus, kaum perpilih, kaum yang terpanggil.Keesaan tubuh Kristus sangat dijujung oleh Paulus, dengan prinsip teologisnya,sekali orang dibaptis dalam Kristus.Kita mengenakan Kristus, tidak mungkin lagi ada pemisahan antara Yahudi dan non-Yahudi, budak dan orang merdeka, laki-laki dan perempuan, tetapi telah satu di dalam Kristus Yesus.

\section{DAFTAR PUSTAKA}

Bauckhman, Richard. 1993. Teologi Mesianis. Jakarta: BPk Gunung Mulia

Conn, Harvie M. 1985. Teologia Semesta Kontemporer. Malang: Gandum Mas

Hadiwijono, Harun. 2000. Teologi Reformatoris abad Ke 20. Jakarta: BPK Gunung Mulia Lane, Tony. 1990. Runtut Pijar: Sejarah Pemikiran Kristiani. Jakarta: BPK Gunung Mulia

Olson, Roger E, Grenz, Stanley J. dan. ed. 1992.Twentieth Century Theology. Downers Grove: InterVarsity Press. 
Smith, David L. 2000. Handbook Contemporary Theology. Grand Rapids: Bridgepoint Books

Wikipedia Bahasa Indonesia, Ensiklopedia bebas, Jurgen Moltmann, download tanggal 8 November 2011, tersedia di id.wikipedia.org/wiki/Jürgen_Moltmann

\section{Lampiran}

Nama Lengkap : Ezra Tari

Alamat : Jl. Untung Surapati, Gang Kincir RT 11, Rw 5, Kupang Nusa Tenggara Timur

Gelar Akademik : M.Th

Almamater : STT Jaffray Makassar

Jabatan Terakhir : Dosen

Bidang Pelayanan dan Minat : Koloqium Perjanjian Baru 